\title{
Changes in vegetation and soil seed bank of meadow after waterlogging caused by Castor fiber
}

\author{
Magdalena Franczak*, Bożenna Czarnecka \\ Department of Ecology, Faculty of Biology and Biotechnology, Maria Curie-Skłodowska University, Akademicka 19, 20-033 Lublin, Poland
}

\begin{abstract}
Soil waterlogging is among abiotic stresses that influence species composition and productivity in numerous plant communities. The aim of the study was to find answer to the question of how waterlogging caused by beavers' activity induces quantitative and qualitative changes of vegetation and soil seed bank levels of variable-moist meadows.

An immediate effect of the waterlogging at the level of vegetation was the decline in species richness and a decrease in the values of the biodiversity index. Water stress inhibited growth and development of plants already present and, primarily, impeded recruitment of new individuals of species characteristic of variable-moist meadows, e.g. Cirsium rivulare, Filipendula ulmaria and Lythrum salicaria, which were replaced by Carex acutiformis. Prolonged waterlogging did not induce equally substantial changes in the soil seed bank as in the vegetation. Both in the waterlogged and control patches, slightly decreased species richness and biodiversity index were recorded. After waterlogging withdrawal, the reserves of the soil seed bank were slightly higher than the initial values. The differences were not statistically significant.

In the waterlogged patch, the qualitative floristic similarity between taxa identified in the soil seed bank and vegetation cover declined, which was evidenced by the value of Jaccard's index decreasing from 0.46 to 0.36 . A reverse relationship was found in control patch, where the value of the similarity index slightly increased from 0.41 to 0.48 .
\end{abstract}

Keywords: waterlogging; vegetation; soil seed bank; variable-moist meadow; Castor fiber

\section{Introduction}

Changes in habitat moisture are one of the key factors affecting the variability of plant communities and their constituent species populations. Both excess and deficiency of water in the substrate may be a potential stress factor [1]. Given the most common effects of anthropogenic transformation of wet habitats, a substantial number of publications are focused on the impact of desiccation on changes occurring at the level of vegetation, population, and soil seed bank [2-5]. Seasonal floods and prolonged waterlogging caused by stagnation of water in the catchment area are equally important factors exerting a considerable effect on species dynamics and vegetation of hydrogenic areas [6-9].

Waterlogging during the vegetation season limits plant growth by among others, causing damage to the assimilation organs associated with accumulation of toxic products of anaerobic respiration $[10,11]$. Changes in light intensity or soil properties may result in a population decline caused by death of water stress-exposed individuals and/or in modification of selected characteristics of their life history

\footnotetext{
*Corresponding author. Email: mpelc4@wp.pl
}

Handling Editor: Aleksandra Samecka-Cymerman by reduction of biomass or changing the pattern of biomass allocation as well as decreasing vegetative and/or generative propagation [12-18]. Seed bank reserves in the soil have a fundamental role in maintenance of plant communities under long-term stress caused by waterlogging. The ability of seeds of individual taxa to maintain viability in waterlogging conditions and develop a persistent seed bank increases the chance for limiting the adverse effects of waterlogging at the population and phytocoenosis levels [19-21]. The dynamic character of flood-meadows is reflected by a large proportion of species with a strong tendency to accumulate seeds in the soil relative to their importance in vegetation [22]. The similarity between aboveground vegetation and the soil seed bank is expected to decrease with increasing community stability and stress, due to a lack of disturbances creating sites for germination from the seed bank and higher investment in clonal instead of sexual reproduction in stressful conditions [23].

Sudden changes in the water level within the floodplain of river valleys are repeatedly caused by the activity of the European beaver Castor fiber. Lodges and dams built by beavers impede water flow from catchments, which causes local flooding of neighboring areas [24,25]. The presence of beaver ponds reduces the velocity of water runoff and contributes to diminish the erosion processes and increased 
sediment deposition. The effect of beaver dams on stream flow will vary according to their location in the catchment. In narrow upland valleys, beaver ponds are generally small, whereas in floodplain areas, even a low dam can flood a relatively large surface area [26,27].

The C. fiber is regarded as a model of "environmental engineer", an organism that directly or indirectly modulates the availability of resources to other species by causing physical changes in biotic and abiotic matter. Beavers create, modify, or maintain existing habitats and affect energy and matter flows in ecosystems by creating or destroying living space and thereby altering environments of other organisms [28-31]. They increase heterogeneity and habitat and species diversity at the landscape scale. This species probably plays a key role in ecosystem processes, because its foraging has a considerable impact on the course of succession, species composition, and structure of plant communities. Beavers are among the few species besides humans that can significantly change the geomorphology and, consequently, the hydrological characteristics and biotic properties of the landscape [25].

The aim of the study was to find answers to the questions of $(i)$ how waterlogging caused by beavers' activity induces quantitative and qualitative changes of vegetation and soil seed bank levels of variable-moist meadows; (ii) how does the similarity between the floristic composition of the analyzed vegetation patches and the soil seed bank form before and after waterlogging?

\section{Material and methods}

\section{Study area}

The research was carried out in the Szum River valley in the Roztocze Highland region, SE Poland (Fig. 1). The Szum River is a $24-\mathrm{km}$-long stream with a ca. $84-\mathrm{km}^{2}$ catchment area and flows verging from 401 to $615 \mathrm{dm}^{3} \mathrm{~s}^{-1}$. The Szum

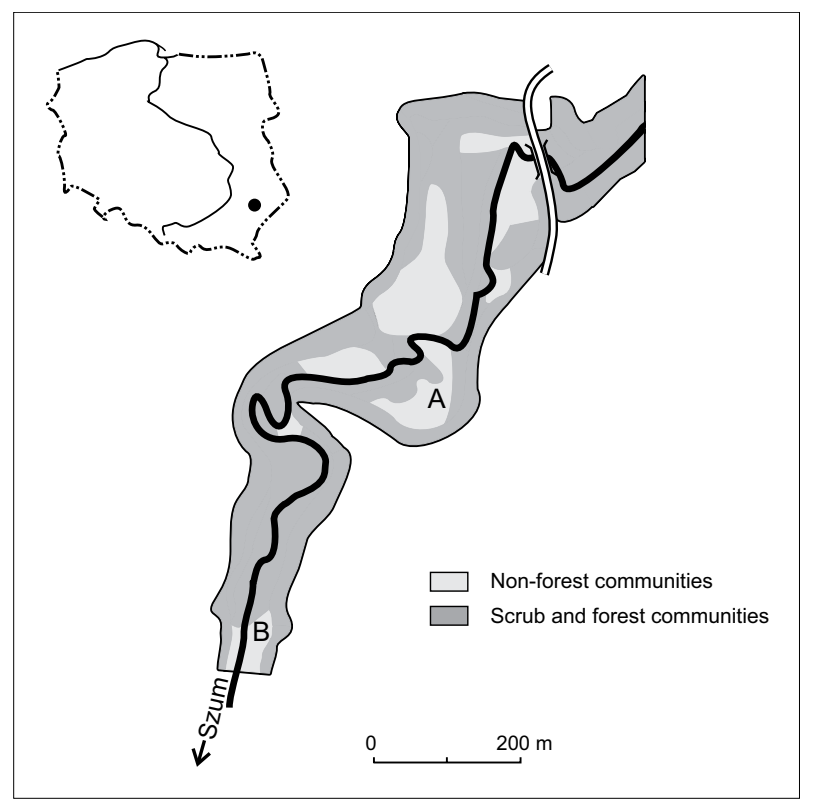

Fig. 1 Situation of the study area in the Szum River valley; A, B - study patches (Czarnecka [34], slightly changed).
River valley is characterized by high phytocoenotic and floristic diversity, which is an effect of the mosaic structure of habitats and a nearly nine-fold variability of the surface and groundwater mineralization level $[32,33]$. In total, 48 types of plant communities belonging to different ecological groups have been identified along the 4-km-long fragment of the Szum River valley. The vascular plant flora of the area comprises 378 species representing 72 families [34].

The vegetation has developed on meso- and euthrophic peaty-gley and mud-gley soils with different levels of groundwater. The meadow communities were dominated by macroforbes: Filipendula ulmaria, Lysimachia vulgaris, Lythrum salicaria, Cirsium rivulare, C. oleraceum, and Mentha longifolia. The rush phytocoenoses were composed mainly of Carex acutiformis and Phragmites australis.

During the growing season in 2006, the groundwater levels in a fragment of the Szum River valley rose as a consequence of the activity of European beavers Castor fiber. The dam built by beavers impeded water outflow from the catchment and led to water stagnation and flooding. At the end of 2007, catchment waters began to flow into the river, after beavers discontinued strengthening the dam. Consequently, the water level in the waterlogged fragment of the valley was lowered.

\section{Field study}

The investigations were conducted in two permanent plots $(5 \times 5 \mathrm{~m})$ located in two vegetation patches " $\mathrm{A}$ " and " $\mathrm{B}$ " representing the association Lysimachio vulgaris-Filipenduletum (Fig. 1). Patch A (ca. $250 \mathrm{~m}^{2}$ area) was situated on a flat, vast floodplain ca. $50 \mathrm{~m}$ away from the fragment of the riverbed where beavers had built the dam. During the study, the patch was flooded. Patch B (ca. $200 \mathrm{~m}^{2}$ area) developed on the floodplain at the distance of approximately $400 \mathrm{~m}$ downstream from patch $\mathrm{A}$. The patch $\mathrm{B}$ was not affected by waterlogging and served as a control.

In order to identify the hydrological conditions, five piezometers were placed next to each plot. In the vegetation seasons 2006-2009, the water level was measured relative to the surface with an accuracy of $1 \mathrm{~cm}$. In 2006-2007, the groundwater level was determined monthly from April to October, while in 2008 and 2009 - in April, June, August, and October. The graphic presentation of the fluctuations of the groundwater levels provides averaged values from all the piezometers installed in each patch.

The floristic composition of the vegetation was monitored in the growing seasons of 2006-2009. An eleven-grade species cover scale ("+" for a species with cover less than $5 \%$, “ 1 ” for cover $5-10 \%$, , 2 " - 11-20\%, .., “ $10 "-91-100 \%)$ was used [35].

The soil seed bank was sampled twice, i.e. in March 2006 and March 2009. Soil samples were taken with the Kopecky's cylinder $(100 \mathrm{ml}$ each, $5 \mathrm{~cm}$ deep, the surface area of one sample $-19.7 \mathrm{~cm}^{2}$ ) from the surrounding area of plots A and B, 64 for each plot. Samples were not collected from surface of plots to avoid a damage of the structure of vegetation. We analyzed the soil seed bank by the seedling emergence method for 20 months [36,37]. The soil samples were sorted to eliminate plant fragments and placed in cold frames in an experimental garden. In order to eliminate the input of 
seeds from surrounding habitats, frames were covered by windows. During the study, in soil samples the seedling of species present in the garden and its surrounding were not observed. The soil was regularly watered. Emerging seedlings were identified using available literature $[38,39]$ and removed. In the case of identification problems, the seedlings were transplanted into a separate container and observed further until emergence of morphological characteristics that allowed identification of the taxon. During the experiment, the soil samples were carefully turned over in order to facilitate emergence of new seedlings. In the winter months, the analyzed material remained in the garden in order to ensure habitat conditions close to natural ones.

\section{Data analysis}

Assessment of the significance of the changes in the water level noted in the patches during the successive study seasons was performed using the Friedman test.

The Shannon-Wiener and evenness coefficients were used to evaluate the biodiversity of the vegetation and soil seed bank. The Wilcoxon's test was chosen to check the significance of the differences among the means (mean number of taxa, number of seedling per $1 \mathrm{~m}^{2}$, Shannon-Wiener and evenness indices) for the soil seed bank data collected from the same plot before and after waterlogging (2006 and 2009 years).
The qualitative similarity between the vegetation and soil seed bank samples was calculated using Jaccard's index [40]. The index also revealed similarity between the floristic composition in the analyzed patches before and after the waterlogging (2006 and 2009). The same analysis was performed for the floristic data from the soil seed bank. Spearman's rank correlation coefficient was used for comparison of the quantitative structure of the soil seed bank and vegetation cover before and after the waterlogging.

Species recorded in the vegetation and soil seed bank were classified into the following ecological groups: rush, meadow, bog-alder, peat-bog, and ruderal species. Accompanying species and species characteristic for other habitats were defined as "others".

The nomenclature of the vascular flora follows Mirek et al. [41] and the classification of plant communities follows Matuszkiewicz [42]. Statistical calculations were performed using the Statistica 8 software package.

\section{Results}

\section{Changes in water conditions in the study area}

A rapid increase in the groundwater level was recorded in patch A in the summer of 2006 (Fig. 2). In April 2006, water persisted at a depth of several centimeters below the
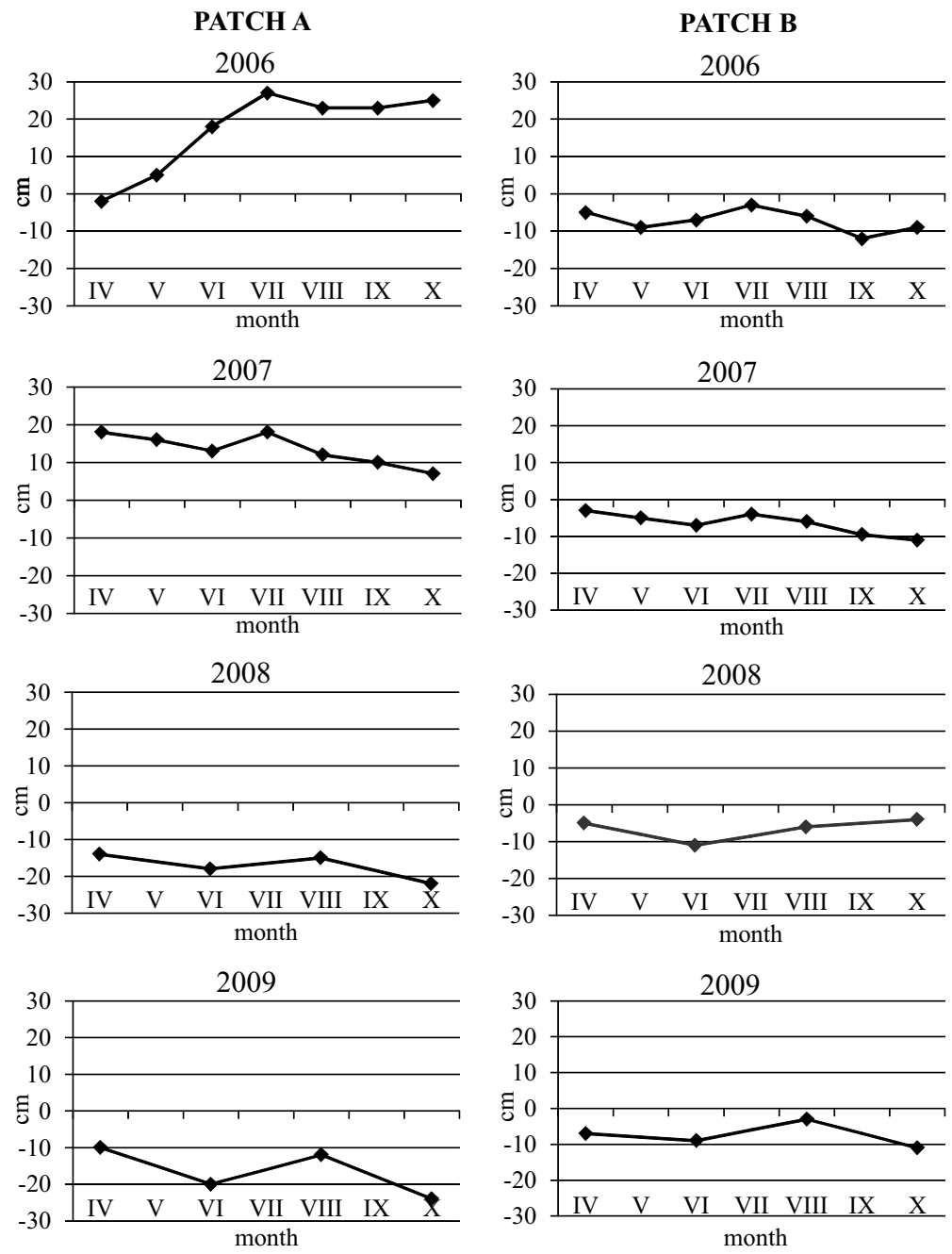

Fig. 2 Changes in the level of groundwater in patches A and B in the years 2006-2009. 
ground surface. During the whole vegetation season, the water level rose by several centimeters (with a maximum in July $-28 \mathrm{~cm}$ ). Waterlogging persisted until the end of the growing season in 2007, when catchment waters began to flow into the river after beavers had ceased strengthening the dam. In 2008-2009, no stagnant water was found on the surface even after intensive precipitation, and the maximum water levels remained at $10 \mathrm{~cm}$ below the ground surface. The differences in the water levels in patch A during the consecutive study seasons were statically significant $\left(\chi^{2}=\right.$ 17.57; $P=0.0005$ ).

The water table in patch B was very shallow; yet, it was not observed to be higher than the ground surface. The minimum water levels reached $-12 \mathrm{~cm}$, while at the maximum levels water stagnated immediately below the surface. No statistically significant differences were found in the course of the water levels in the different vegetation seasons $\left(\chi^{2}=\right.$ $1.48 ; P=0.0847)$.

\section{Influence of waterlogging on the vegetation}

During the 4-year observation, 42 vascular plant species were recorded in patches A and B (Appendix S1). Among all the species identified, 26 were common for both patches with Carex acutiformis, Filipendula ulmaria, Lysimachia vulgaris, and Lythrum salicaria as the most abundant.

In the second growing season, a rapid decline in species richness by more than $50 \%$ was observed in the waterlogged patch A (Tab. 1). In 2008-2009, the number of taxa increased after waterlogging withdrawal but it did not reach the initial value. Concurrently, the value of the biodiversity index decreased from 1.31 in the vegetation season of 2006 to 0.89 in the following year. This phenomenon was accompanied by a decrease in the value of the evenness coefficient from 0.90 to 0.77 . In the control patch B, the number of species decreased slightly in 2006-2008, but these changes were not as large as in the waterlogged patch $\mathrm{A}$. The values of the Shannon-Wiener and evenness indices oscillated at similar levels throughout the observation period (1.27-1.34 and 0.89-0.90, respectively).

Jaccard's indices revealed more remarkable changes in the species composition in patch $\mathrm{A}(J=0.48)$ than in patch $\mathrm{B}(J=0.63$; Appendix $\mathrm{S} 1)$. The decline in species richness in patch A induced by waterlogging (2007) was affected to reduction of the share of meadow species (e.g. Cirsium rivulare, F. ulmaria, Lychnis flos-cuculi) and a slight increase in the share of rush species. After waterlogging withdrawal, a reverse tendency was observed, i.e. the share of meadow species increased from 42.9 to $57.9 \%$ and that of rush species decreased from 28.6 to $15.8 \%$ (Tab. 2). Species that proved to be the most resistant to water stress, as their cover before and after the waterlogging remained at a comparable level or increased, included e.g. C. acutiformis, Eupatorium cannabinum, Glyceria maxima, L. vulgaris, Mentha longifolia and Thelypteris palustris.

\section{Influence of waterlogging on the density and \\ floristic composition of the soil seed bank}

In total, 42 taxa were recorded during the observations of emergence of seedlings from the soil seed bank (Appendix S1). The numbers of taxa identified in patches
A and B were comparable and amounted to 32 and 34, respectively. Over $85 \%$ of all the taxa were noted during the first year of the observation of the soil seed bank. Prolonged waterlogging did not induce equally substantial changes in the soil seed bank as in the plant cover. Both in the waterlogged and control patch, slightly reduced species richness and decreased values of the biodiversity index were recorded, but the differences, in the majority, did not change statistically significant (Tab. 1).

After waterlogging withdrawal, the reserves of the soil seed bank in patch A were slightly higher than the initial values (3768 and 3858 seedlings per $\mathrm{m}^{2}$, respectively). At that time, the number of seedlings in patch $B$ decreased from 5087 to 4536 per $\mathrm{m}^{2}$. The differences were not statistically significant. In all samples, the seeds of Carex acutiformis, Lysimachia vulgaris, and Lythrum salicaria had a largest abundance. An increase in the share of a majority of the distinguished species groups, particularly meadow species, was observed in both patches (Tab. 2). Taxa that increased their number of seedlings in the soil seed bank from patch A include e.g. C. acutiformis, Crepis paludosa, Galium palustre, L. vulgaris, L. salicaria and representatives of Poaceae. In the control patch, the density of seedlings of the aforementioned species in the second study period generally exhibited lower values than those in 2006 (Appendix S1).

\section{Similarity between vegetation and the soil seed bank}

In the waterlogged patch $A$, the qualitative floristic similarity between taxa identified in the soil seed bank and vegetation cover declined, which was evidenced by the value of Jaccard's index decreasing from 0.46 to 0.36 . A reverse relationship was found in patch $B$, where the value of the similarity index increased from 0.41 to 0.48 .

The results of the analysis of quantitative similarity expressed by Spearman's coefficient before waterlogging indicate a low but statistically significant $(P<0.05)$ correlation between the abundance of the taxa identified in the vegetation cover and the soil seed bank (Tab. 3). Waterlogging caused a decrease in the quantitative similarity in patch A from 0.38 to 0.11 , whereas the value of the correlation coefficient in the control patch increased from 0.10 to 0.43 .

\section{Discussion}

As an engineer species, the beaver Castor fiber can significantly change the geomorphological, hydrological, and biotic properties of the landscape $[25,43]$. The species creates patches that are sufficiently different from surrounding patches so that species otherwise excluded from the landscape can persist. One would predict that the addition of an engineer to the landscape should increase species richness by increasing habitat heterogeneity [30]. An increase in richness within engineered patches is typically thought to be a result of disturbance increasing resources by eliminating competitively dominant species or ameliorating stressful conditions [44]. Alternatively, a decrease in species richness could occur if the conditions created by the engineer facilitate the growth of a competitive dominant, or are so harsh as to eliminate most species [30]. An example of such a factor 
Tab. 1 Differentiation of number of taxa, Shannon-Wiener and evenness indices in the vegetation and soil seed bank.

\begin{tabular}{|c|c|c|c|c|c|c|c|c|c|c|c|c|c|c|}
\hline & \multicolumn{7}{|c|}{ Patch A } & \multicolumn{7}{|c|}{ Patch B } \\
\hline & \multicolumn{4}{|c|}{ Vegetation } & \multicolumn{3}{|c|}{ Seed bank } & \multicolumn{4}{|c|}{ Vegetation } & \multicolumn{3}{|c|}{ Seed bank } \\
\hline & 2006 & 2007 & 2008 & 2009 & 2006 & 2009 & $P$ & 2006 & 2007 & 2008 & 2009 & 2006 & 2009 & $P$ \\
\hline $\begin{array}{l}\text { Number of } \\
\text { taxa }\end{array}$ & 29 & 14 & 19 & 20 & 28 & 25 & n. s. & 31 & 28 & 26 & 26 & 28 & 24 & n. s. \\
\hline $\begin{array}{l}\text { Number of } \\
\text { seedlings (per } \\
\mathrm{m}^{2} \text { ) }\end{array}$ & & & & & 3768 & 3858 & n. s. & & & & & 5087 & 4536 & n. s. \\
\hline $\begin{array}{l}\text { Shannon- } \\
\text { Wiener index }\end{array}$ & 1.31 & 0.89 & 1.02 & 1.08 & 1.16 & 0.95 & n. s. & 1.34 & 1.29 & 1.28 & 1.27 & 1.04 & 1.02 & n. s. \\
\hline $\begin{array}{l}\text { Evenness } \\
\text { index }\end{array}$ & 0.90 & 0.77 & 0.79 & 0.83 & 0.81 & 0.68 & 0.05 & 0.90 & 0.89 & 0.90 & 0.90 & 0.71 & 0.74 & n. s. \\
\hline
\end{tabular}

The significance of the differences among the means for the soil seed bank data collected from the same plot before and after waterlogging (2006 and 2009 years) was performed using the Wilcoxon's test. The level of statistical significance for all analyses was at $\alpha=0.05$.

Tab. 2 Percentage distribution of ecological groups of the species in the vegetation and soil seed bank.

\begin{tabular}{|c|c|c|c|c|c|c|c|c|c|c|c|c|}
\hline \multirow{3}{*}{$\begin{array}{l}\text { Ecological } \\
\text { groups }\end{array}$} & \multicolumn{6}{|c|}{ Patch A } & \multicolumn{6}{|c|}{ Patch B } \\
\hline & \multicolumn{4}{|c|}{ Vegetation } & \multicolumn{2}{|c|}{ Seed bank } & \multicolumn{4}{|c|}{ Vegetation } & \multicolumn{2}{|c|}{ Seed bank } \\
\hline & 2006 & 2007 & 2008 & 2009 & 2006 & 2009 & 2006 & 2007 & 2008 & 2009 & 2006 & 2009 \\
\hline Rush species & 23.3 & 28.6 & 15.8 & 15.0 & 14.3 & 16.0 & 9.7 & 10.7 & 7.7 & 15.4 & 10.7 & 12.5 \\
\hline $\begin{array}{l}\text { Meadow } \\
\text { species }\end{array}$ & 50.0 & 42.9 & 57.9 & 55.0 & 39.3 & 52.0 & 58.0 & 57.2 & 57.7 & 53.9 & 46.4 & 54.1 \\
\hline $\begin{array}{l}\text { Bog-alder } \\
\text { species }\end{array}$ & 10.0 & 7.1 & 10.5 & 10.0 & 3.6 & 4.0 & 9.7 & 10.7 & 15.4 & 15.4 & 3.6 & 4.2 \\
\hline $\begin{array}{l}\text { Peat-bog } \\
\text { species }\end{array}$ & & & & 5.0 & & & & & 3.8 & 3.8 & 3.6 & \\
\hline $\begin{array}{l}\text { Ruderal } \\
\text { species }\end{array}$ & 6.7 & 7.1 & 10.5 & 5.0 & 7.1 & 8.0 & 9.7 & 7.1 & 7.7 & 3.8 & 3.6 & 4.2 \\
\hline Others species & 10.0 & 14.3 & 5.3 & 10.0 & 35.7 & 20.0 & 12.9 & 14.3 & 7.7 & 7.7 & 32.1 & 25.0 \\
\hline
\end{tabular}

Tab. 3 Comparison of the structure of the soil seed bank and vegetation before and after the waterlogging using Spearman's rank correlation coefficient.

\begin{tabular}{|c|c|c|c|}
\hline \multicolumn{2}{|c|}{ Patch A } & \multicolumn{2}{|c|}{ Patch B } \\
\hline 2006 & 2009 & 2006 & 2009 \\
\hline $0.38 ; P<0.05$ & $0.11 ;$ n.s. & 0.10 ; n.s. & $0.43 ; P<0.05$ \\
\hline
\end{tabular}

may be the sudden rise in the groundwater level and longterm stagnation on the surface, as observed in the analyzed fragment of the Szum River valley.

Soil waterlogging is among abiotic stresses that influence species composition and productivity of numerous plant communities. Tolerance to flooding and waterlogging determines the spatial distribution of many plant species in wetlands [11]. Excess water in the environment can be treated as a stress factor sensu Grime [1]. Flood-tolerant species have a wide range of plasticity to adjust their physiology resulting in metabolic, morphological, and anatomical acclimation $[45,46]$.

An immediate effect of the waterlogging of patch $A$ at the level of vegetation was the decline in species richness and a decrease in the values of the biodiversity index. Stress sensu Grime [1] induced by periodic anaerobic conditions [8,12,47] inhibited the growth and development of plants already present and, primarily, impeded recruitment of new individuals of species characteristic of variable-moist meadows, e.g. Cirsium rivulare, Filipendula ulmaria and Lythrum salicaria, which were replaced by Carex acutiformis. This is associated with the high tolerance of sedges to anaerobic conditions [48] and the capability of vegetative (clonal growth) propagation of their individuals. Consequently, patch A representing the association Lysimachio vulgaris-Filipenduletum, prior to the waterlogging, was transformed into the Carex acutiformis community. The qualitative changes that took place in this patch in 2006-2009 are additionally confirmed by the 
relatively small number of common species (Jaccard' index $=0.48$ ). A similar relationship was observed by Kobojek [49] in the Rawka River valley (central Poland), where C. fiber had been reintroduced. The activity of the animal resulted in a rise in the groundwater level and an increase in the share of rush and aquatic vegetation.

The impact of beavers' activity on biodiversity is ambiguous. While the effects at the level of the landscape are easily discernible (dams, small reservoirs, elimination of shrubs and trees), at the phytocoenotic level (vegetation patches) both increased [30] and decreased species diversity [50] can be observed. The question of the duration of the impact exerted by the landscape structure elements built and abandoned by beaver "engineers" seems interesting. The colony of beavers left the study area already after three seasons. Although beaver dams are relatively short-term forms (typically $<10$ years), their impact on surrounding biocoenoses may persist for as long as several decades [51].

Under natural conditions, seeds in the soil will be metabolically active and will therefore be vulnerable to oxidative deterioration processes. Increased water content in the soil could therefore be beneficial for seed survival. On the other hand, effects of long periods of waterlogging could be negative when anoxic conditions occur [20].

In total, 42 taxa, a majority of which represented meadow species, were identified in the soil seed bank of the investigated vegetation patches in the Szum River valley. Despite the considerable changes in the species composition in patch $\mathrm{A}$ induced by waterlogging, the reserves of the soil seed bank remained at a comparable level. Most taxa that were present in 2006, e.g. Juncus effusus, Lycopus europaeus, Lychnis flos-cuculi, and Scutellaria galericulata, were identified in the soil samples. These species, however, were not found in the

\section{Acknowledgments}

We would like to thank Dr. Joanna Czarnecka for helping in soil seed bank methodology, and Mrs. Anna Wesołowska-Zoń for improving our English. Research was supported financially by the Department of Ecology, Institute of Biology and Biochemistry, Maria Curie-Skłodowska University.

\section{Authors' contributions}

The following declarations about authors' contributions to the research have been made: design of the study: MF, BC; field work: MF, BC; laboratory work: MF; writing the manuscript: MF, BC.

\section{Competing interests}

No competing interests have been declared.

\section{Supplementary material}

The following supplementary material for this article is available online at http://pbsociety.org.pl/journals/index.php/asbp/rt/suppFiles/ asbp.2015.018/0:

1. Appendix S1: characteristic of vegetation and soil seed bank structure (number of seedlings per $\mathrm{m}^{2}$ ).

\section{References}

1. Grime JP. Plant strategies, vegetation processes and ecosystem properties. New York, NY: Wiley \& Sons; 2001.

2. Grootjans AP, van Diggelen R, Wassen MJ, Wiersinga WA. The effects of drainage on groundwater quality and plant species distribution in stream valley meadows. Vegetatio. 1988;75(1-2):37-48. http://dx.doi. org/10.1007/BF00044624 vegetation cover after the waterlogging. Given the distinct isolation of the investigated vegetation patches, the authors exclude the possibility of seed dispersal from the neighboring communities. Hence, one can put forward a hypothesis that at least partial restoration of the pre-waterlogging species composition in patch $\mathrm{A}$ is possible. This will definitely be promoted by the persistent seed bank of some species characteristic for tall herbs of variable-moist meadows [52]. The results of an analysis of the size and floristic composition of the soil seed bank in successive stages of ecological succession in abandoned meadow communities in the Narewka River valley (NE Poland) demonstrate persistence of the seed bank [53]. After 20 years of observation, it was found that $67 \%$ of the taxa identified in the soil seed bank were meadow species, a majority of which had been absent from the vegetation cover for many years. Most species maintained viability for as long as $10-15$ years. The author [53] excluded the possibility of migration of the seeds of these species from neighboring communities. In our study, it was found that after waterlogging withdrawal the share of meadow species in patch A increased from 39 to $52 \%$. Factors that impeded restoration of the plant cover included dominance of C. acutiformis and production of large quantities of necromass by this species as well as the further process of succession towards willow and alder scrub communities, which led to deterioration of light conditions.

The soil seed bank is generally considered an important factor influencing community dynamics. The reserve of propagules in soil facilitates regeneration of plant communities [54]. Species recruitment from the soil seed bank can be promoted by all microscale disturbances leading to formation of gaps in the dense vegetation cover that can play the role of a potential regeneration niche $[55,56]$.

3. Grootjans AP, Hunnemana H, Verkielb H, van Andel J. Long-term effects of drainage on species richness of a fen meadow at different spatial scales. Basic Appl Ecol. 2005;6(2):185-193. http://dx.doi. org/10.1016/j.baae.2005.01.008

4. Roy V, Ruel JC, Plamondon AP. Establishment, growth, survival of natural regeneration after clearcutting and drainage on forested wetlands. For Ecol Manage. 2000;129(1-3):253-267. http://dx.doi. org/10.1016/S0378-1127(99)00170-X

5. Sarkkola S, Hokka H, Lacho R, Paivanen J, Penttila T. Stand structural dynamics on drained peatlands dominated by Scots pine. For Ecol Manage. 2005;206(1-3):135-152. http://dx.doi.org/10.1016/j. foreco.2004.10.064

6. Blom CWPM. Adaptations to flooding stress: from plant community to molecule. Plant Biol. 1999;1(3):261-273. http://dx.doi. org/10.1111/j.1438-8677.1999.tb00252.x

7. Lenssen JPM, Menting FBJ, van der Putten WH, Blom WPM. Vegetative reproduction by species with different adaptations to shallowflooded habitats. New Phytol. 2000;145(1):61-70. http://dx.doi. org/10.1046/j.1469-8137.2000.00557.x

8. Lenssen JPM, Menting FBJ, van der Putten WH. Plant responses to simultaneous stress of waterlogging and shade: amplified or hierarchical effects? New Phytol. 2003;157(2):281-290. http://dx.doi. org/10.1046/j.1469-8137.2003.00666.x

9. Kotowski W, van Andel J, van Diggelen R, Hogendorf J. Responses of fen plant species to groundwater level and light intensity. Plant Ecol. 2001;155(2):147-156. http://dx.doi.org/10.1023/A:1013214716842

10. Gibbs J, Greenway H. Mechanisms of anoxia tolerance in plants. 
I. Growth, survival and anaerobic catabolism. Funct Plant Biol. 2003(1);30:1-47. http://dx.doi.org/10.1071/PP98095

11. Jackson MB, Colmer TD. Response and adaptation by plants to flooding stress. Ann Bot. 2005;96(4):501-505. http://dx.doi.org/10.1093/ aob/mci205

12. Vartapetian BB, Jackson MB. Plant adaptations to anaerobic stress. Ann Bot. 1997;79(A suppl): 3-20. http://dx.doi.org/10.1093/oxfordjournals.aob.a010303

13. Clevering OA. Effects of litter accumulation and water table on morphology and productivity of Phragmites australis. Wetlands Ecology and Management. 1998;5(4):275-287. http://dx.doi. org/10.1023/A:1008233912279

14. Edwards AL, Lee DW, Richards JH. Responses to a fluctuating environment: effects of water depth on growth and biomass allocation in Eleocharis cellulosa Torr. (Cyperaceae). Can J Bot. 2003;8:964-975. http://dx.doi.org/10.1139/B03-091

15. Warwick NM, Brock MA. Plant reproduction in temporary wetlands: the effects of seasonal timing, depth, and duration of flooding. Aquat Bot. 2003;77(2):153-167. http://dx.doi.org/10.1016/ S0304-3770(03)00102-5

16. Lenssen JPM, van Kleunen M, Fischer M, de Kroon H. Local adaptation of the clonal plant Ranunculus reptans to flooding along a small-scale gradient. J Ecol. 2004;92(4):696-706. http://dx.doi. org/10.1111/j.0022-0477.2004.00895.x

17. Mommer L, Visser EJW. Underwater photosynthesis in flooded terrestrial plants: a matter of leaf plasticity. Ann Bot. 2005;96(4):581-889. http://dx.doi.org/10.1093/aob/mci212

18. Huber H, Jacobs E, Visser EJW. Variation in flooding-induced morphological traits in natural populations of white clover (Trifolium repens) and their effects on plant performance during soil flooding. Ann Bot. 2009;103(2):377-386. http://dx.doi.org/10.1093/aob/mcn149

19. McDonald AW, Bakker JP, Vegelin K. Seed bank classification and its importance for the restoration of species-rich flood-meadows. J Veg Sci. 1996;7(2):157-164. http://dx.doi.org/10.2307/3236315

20. Bekker RM, Oomes MJM, Bakker JP. The impact of groundwater level on soil seed bank survival. Seed Sci Res.1998;8(3):399-404. http:// dx.doi.org/10.1017/S0960258500004323

21. Hölzel N, Otte A. The impact of flooding regime on the soil seed bank of flood-meadows. J Veg Sci. 2001;12(2):209-218. http://dx.doi. org/10.2307/3236605

22. Hölzel N, Otte A. Assessing soil seed bank persistence in floodmeadows: the search for reliable traits. J Veg Sci. 2004;15(1):93-100. http://dx.doi.org/10.1111/j.1654-1103.2004.tb02241.x

23. Bonis A, Lepart J, Grillas P. Seed bank dynamics and coexistence of annual macrophytes in a temporary and variable habitat. Oikos. 1995;74(1):81-92. http://dx.doi.org/10.2307/3545677

24. Gurnell AM. The hydrogeomorphological effects of beaver dambuilding activity. Prog Phys Geogr. 1998;22(2):167-189. http://dx.doi. org/10.1191/030913398673990613

25. Rosell F, Bozśer O, Collen P, Parker H. Ecological impact of beavers Castor fiber and Castor canadensis and their ability to modify ecosystems. Mamm Rev. 2005;35(3-4):248-276. http://dx.doi. org/10.1111/j.1365-2907.2005.00067.x

26. Johnston CA, Naiman RJ. Boundary dynamics of the aquatic-terrestrial interface: the influence of beaver and geomorphology. Landsc Ecol. 1987;1(1):47-57. http://dx.doi.org/10.1007/BF02275265

27. Westbrook CJ, Cooper DJ, Baker B. Beaver dams and overbank floods influence groundwater - surface water interactions of a Rocky Mountain riparian area. Water Resour Res. 2006;42(6):1-12. http:// dx.doi.org/10.1029/2005WR004560

28. Jones CG, Lawton JH, Shachak M. Organisms as ecosystem engineers. Oikos. 1994;69(3):373-386. http://dx.doi.org/10.2307/3545850

29. Jones CG, Lawton JH, Shachak M. Positive and negative effects of organisms as physical ecosystem engineers. Ecology. 1997(7);78:19461957. http://dx.doi.org/10.2307/2265935

30. Wright JP, Jones CG, Flecker AS. An ecosystem engineer, the beaver, increases species richness at the landscape scale. Oecologia. 2002;132(1):96-101. http://dx.doi.org/10.1007/s00442-002-0929-1

31. Wright JP, Jones CG. The concept of organism as ecosystem engineers ten years on: progress, limitations, and challenges. BioScience. 2006;56(3):203-209. http://dx.doi.org/10.1641/00063568(2006)056\%5B0203:TCOOAE\%5D2.0.CO;2

32. Czarnecka B, Janiec B. Abiotic conditions affecting the biodiversity of the "Szum" landscape reserve in Roztocze. Ekologia (Bratislava). 2001;20(4 suppl):207-214.

33. Czarnecka B, Janiec B. River breaks of Roztocze region as model objects in environmental education. Lublin: Maria Curie-Skłodowska University Press; 2002.

34. Czarnecka B. Plant cover of the Szum River valley (Roztocze, southeast Poland). Acta Soc Bot Pol. 2005;74(1):43-51. http://dx.doi. org/10.5586/asbp.2005.008

35. Dzwonko Z. Guidebook to phytosociological studies. Poznań: Sorus Press; 2007.

36. Gross KL. A comparison of method for estimating seed number in the soil. J Ecol. 1990;78(4):1079-1093. http://dx.doi.org/10.2307/2260953

37. Thompson K, Bakker JP, Bekker RM. The soil seed banks of north west Europe: methodology, density and longevity. Cambridge: Cambridge University Press; 1997.

38. Csapodỳ V. Keimlingsbestimmungsbuch der Dikotyledonen. Budapesti: Akademiai Kiado; 1968.

39. Muller FM. Seedlings of the north-western European lowland. A flora of seedlings. The Hague: Dr W. Junk B.V. Publishers; 1978. http:// dx.doi.org/10.1007/978-94-009-9981-7

40. Krebs CJ. Ecology. The experimental analysis of distribution and abundance. Warszawa: Polish Scientific Publishers PWN; 2011.

41. Mirek Z, Piękoś-Mirkowa H, Zając A, Zając M, editors. Flowering plants and pteridophytes of Poland - a checklist. Kraków: W. Szafer Institute of Botany, Polish Academy of Sciences; 2002. (Biodiversity of Poland; vol 1).

42. Matuszkiewicz W. The guide for identification of Polish plant communities. Warszawa: Polish Scientific Publishers PWN; 2008.

43. Nolet BA, Rosell F. Comeback of the beaver Castor fiber: an overview of old and new conservation problems. Biol Conserv. 1998;83(2):165-173. http://dx.doi.org/10.1016/S0006-3207(97)00066-9

44. Hacker SD, Gaines SD. Some implications of direct positive interactions for community species diversity. Ecology. 1997;78(7):1990-2003. http://dx.doi.org/10.2307/2265939

45. Bailey-Serres J, Voesenek LACJ. Flooding stress: acclimations and genetic diversity. Annu Rev Plant Biol. 2008;59(1):313-339. http:// dx.doi.org/10.1146/annurev.arplant.59.032607.092752

46. Sairam RK, Kumutha D, Ezhilmathi K, Deshmukh PS, Srivastava GC. Physiology and biochemistry of waterlogging tolerance in plants. Biol Plant. 2008;52(3):401-412. http://dx.doi.org/10.1007/ s10535-008-0084-6

47. Ernst WHO. Ecophysiology of plants in waterlogged and flooded environments. Aquat Bot. 1990;38(1):73-90. http://dx.doi. org/10.1016/0304-3770(90)90099-7

48. Visser EJW, Bögemann GM, van de Steeg HM, Pierik R, Blom PM. Flooding tolerance of Carex species in relation to field distribution and aerenchyma formation. New Phytol. 2000;148(1):93-103. http:// dx.doi.org/10.1046/j.1469-8137.2000.00742.x

49. Kobojek E. Environmental effects of the reintroduction of the beaver (Castor fiber) in the Rawka valley. Prz Geogr. 2005;77:383-396.

50. Anderson $\mathrm{CB}$, Rosemond $\mathrm{AD}$. Ecosystem engineering by invasive exotic beavers reduces in-stream diversity and enhances ecosystem function in Cape Horn, Chile. Oecologia. 2007;154(1):141-153. http:// dx.doi.org/10.1007/s00442-007-0757-4

51. Terwilliger J, Pastor J. Small mammals, ectomycorrhizae and conifer succession in beaver meadows. Oikos. 1999;85(1):83-94. http://dx.doi. org/10.2307/3546794

52. Matus G, Verhagen R, Bekker RM. Soil seed bank and vegetation 
composition of two fen-meadow stands in the Netherlands. Acta Bot Hung. 2001;43(3):349-366. http://dx.doi.org/10.1556/ ABot.43.2001.3-4.10

53. Falińska K. Seed bank pattern and floristic composition of vegetation patches in a meadow abandoned for 20 years. Fragm Flor Geobot. 2000;45(1-2):91-110.

54. Bekker RM, Verweij GL, Smith REN, Reine R, Bakker JP, Schneider S. Soil seed bank in European grassland: does land use affect regeneration perspectives? J Appl Ecol. 1997;34(5):1293-1310. http://dx.doi. org $/ 10.2307 / 2405239$

55. Grubb PJ. The maintenance of species-richness in plant communities: the importance of the regeneration niche. Biol Rev. 1977;52(1):107145. http://dx.doi.org/10.1111/j.1469-185X.1977.tb01347.x

56. Harper JL. Population biology of plants. London: Academic Press; 1977. 